\title{
ANALISIS KEPEMIMPINAN VISIONER DALAM MEWUJUDKAN VISI MISI SEKOLAH DI MIN I BANTUL
}

\author{
Hascita Istiqomah \\ Program Magister PGMI, UIN Sunan Kalijaga Yogyakarta \\ 18204080046@student.uin-suka.ac.id
}

\begin{tabular}{l} 
INFO ARTIKEL \\
\hline Riwayat Artikel: \\
Diterima: 01-02-2020 \\
Disetujui: 30-04-2020 \\
\end{tabular}

Kata Kunci:

Kepemimpinan,

Visioner,

Visi dan Misi.

Keyword:

Leadership,

Visionary,

Vision and Mission.

\begin{abstract}
ABSTRAK
Abstrak: Penelitian ini bertujuan untuk memberikan informasi terkait dengan kepemimpinan visioner di MIN 1 Bantul." Metode yang digunakan dalam penelitian ini adalah metode kualitatif fenomenologis. Objek penelitian terletak pada Madrasah Ibtidakiyah Negeri 1 Bantul. Adapun Teknik pengumpulan data dalam penelitian ini menggunakan teknik wawancara dengan informan dan pengamatan langsung di lapangan, kemudian dianalisis secara induktif. Hasil penelitian menujukkan bahwa kepala sekolah MIN 1 Bantul memiliki kepemimpinan visioner, hal ini ditunjukkan oleh kepala sekolah MIN 1 Bantul benar-benar memiliki tujuan yang jauh kedepan yaitu menjadikan madrasah sebagai unggulan dan terbaik dari sekolah-sekolah lain. Kemudian mampu bersaing dalam menghadapi perubahan zaman dan globalisasi. Hal ini terlihat dalam tuangan visi dan misi sekolah ini, yang kemudian dapat terealisasi dengan baik dan terus berkembang dari tahun ke tahun berikutnya.
\end{abstract}

\begin{abstract}
This study aims to provide information related to visionary leadership at MIN 1 Bantul. "The method used in this study is a phenomenological qualitative method. The object of research is Madrasah Ibtidakiyah Negeri 1 Bantul. The data collection techniques in this study used the interview technique with informants and direct observations in the field, then analyzed inductively. has a far-reaching goal of making madrassas the best and best from other schools. Then be able to compete in the face of changing times and globalization. This can be seen in the vision and mission of this school, which can then be well realized and continue to grow from year to year.
\end{abstract}

\section{A. LATAR BELAKANG}

Pendidikan di Indonesia seiring dengan perkembangan zaman dan era globalisasi yang sangat pesat menuntut adanya peningkatan mutu pendidikan, pendidikan merupakan komponen yang memiliki peran yang strategis bagi bangsa Indonesia dalam mewujudkan tujuan yang telah dirumuskan. Sekolah merupakan lembaga pendidikan formal yang kedudukannya berperan untuk mempersiapkan anak-anak agar mampu memasuki masyarakat dikemudian hari, yang bermutu tidak sematamata bidang akademik saja yang dituntut, tujuan untuk meletakkan dasar kecerdasan, pengetahuan, kepribadian, akhlak mulia, serta keterampilan untuk

hidup mandiri dan mengikuti pendidikan lebih lanjut. Sesuai pendapat Huda bahwa kemajuan dunia pendidikan di Indonesia diperlukan pendidikan yang bermutu. ${ }^{1}$

Berkembangnya suatu negara ditandai oleh adanya kemajuan pembangunan pendidikan. Hal ini tentu menjadi prioritas bagi setiap bangsa

\footnotetext{
${ }^{1}$ Huda, Muhammad Nailul, Marhadi, Hendri, \& Noviana, Eddy. (2018). Kompetensi Pedagogik Mahasiswa Program Studi Pendidikan Guru Sekolah Dasar. Jurnal Online Mahasiswa (JOM) Bidang Keguruan dan Ilmu Pendidikan, 5(1), 1-13.
}

untuk dapat membangun pendidikan sebaik mungkin agar melahirkan generasi penerus yang berkualitas dalam seluruh aspek serta menciptakan lembaga pendidikan yang efektif dan kompetitif."Salah satu penompang keberhasilan penopang keberhasilan pendidikan tidak akan terlepas dari peran orang tua, guru dan kepala sekolah dalam mewujudkan visi dan misI dari suatu lembaga pendidikan. Suatu visi misi dikatakan berhasil apabila segala upaya yang dilakukan dapat membuahkan hasil yang semakin membaik secara terus menerus atau berkelanjutan. Kepemimpinan menjadi penentu utama terjadinya proses dinamisasi sekolah. Efektifitas kepemimpinan pendidikan tidak bisa lepas dari beberapa aspek yang turut membangun terjadinya efektifitas kepemimpinan sehingga mutu pendidikan akan tercapai. Rohmat mengatakan bahwa fungsi kepemimpinan pendidikan menjadi bagian penting bagi berlansungnya dinamisasi kepemimpinan. ${ }^{2}$

Kemajuan sebuah bangsa ditandai dengan kemajaun pembangunan pendidikaknya. Hal ini tentu menjadi cita-cita setiap bangsa untuk dapat

2 Rohmat, Kepemimpinan Pendidikan, (Purwokerto: STAIN Press, 2010), hlm.1 
membangun pendidikan sebaik mungkin agar melahirkan generasi penerus bangsa yang berkualitas dalam berbagai aspek serta menciptakan lembaga pendidikan yang efektif dan kompetitif. Hal ini tidak luput dari peran orang tua, tenaga pendidik dan kependidikan selaku pemangku kepentingan dalam sekolah. ${ }^{3}$

Di abad ke-21 ini, pendidikan harus dapat mengantisipasi barbagai tuntunan zaman. Pertama, sekolah diharapkan dapat menyelenggarakan program pendidikan yang lebih humanis. ${ }^{4}$

Dalam hal ini kepemimpinan sangat mempengaruhi berjalanya proses pendidikan. Dinamisasi sekolah sebagai organisasi non profit bergantung pada beberapa faktor yang manjadi suatu kesatuan sistem. Semua personel sekolah yang meliputi kepala sekolah, guru, siswa, komite sebagai bentuk perwujudan dari komunitas masyarakat adalah faktor yang sangat mempengaruhi proses dinamisasi sekolah. Komponen sekolah di atas menjadi sistem yang memiliki keterkaitan dalam menuju sekolah yang efektif. Parameter sekolah yang efektif menjadi ukuran keberhasilan sekolah dalam mencapai komitmen sekolah. Output dan outcome sekolah penting dalam menuju keberhasilan sekolah. Prestasi akademik maupun non akademik, serta pembentukan keperibadian siswa merupakan faktor utama bagi sekolah efektif. Semua faktor di atas akan dapat tercapai jika kepemimpinan pendidikan dapat berjalan dengan baik. ${ }^{5}$

Pendidikan dapat dikatakan produktif apabila seorang pemimpin yang mempunyai konsep tentang bagaimana merekayasa masa depan, untuk menciptakan pendidikan yang produktif, menjadikan dirinya agen perubahan, memposisikan sebagai penentu arah organisasi, pelatih atau pembimbing yang profesional, mampu menampilkan kekuatan pengetahuan berdasarkan pengalaman profesional, dan pendidikannya dengan di dukung oleh ciri khas budaya kerja dalam mencapai tujuannya yang ditetapkan dalam visi dan dijabarkan dalam misi, maka dapat dikatakan sebagai kepemimpinan yang visioner. ${ }^{6}$

Kepemimpinan visioner menekankan bahwa keberadaan visi sangat penting bagi organisasi yang ingin mewujudkan organisasi efektif dan kompetitif."Kekuatan menghasilkan berbagai kebijakan dan

\footnotetext{
${ }^{3} \mathrm{Ibid}$,

Tim Dosen Administrasi Pendidikan Universitas Pendidikan Indonesia, Manajemen Pendidikan (Bandung: Alfabeta,2011), hlm.143

5 Muhaimin dan Suti'ah, Manajemen Pendidikan Aplikasinya Dalam Penyusun Rencana Pengembangan Sekolah/Madrasah, (Jakarta : Kencana Prenada Media Group, 2009), hlm.33

6 Tim Dosen Administrasi Pendidikan Universitas Pendidikan Indonesia, Manajemen Pendidikan (Bandung: Alfabeta, 2011), hlm. 143.
}

operasionalisasi kerja yang di bimbing oleh visi organisasi. ."

Pada kenyataannya tidak banyak kepala sekolah yang tahu persis apa tujuannya, visi Sekolah Islam Terpadu (SIT) mereka dan bagaimana mewujudkan visi itu. Padahal, tidak banyak kepala sekolah yang benar-benar memahami makna visi dan misi Sekolah Islam Terpadu (SIT) yang dipimpinnya. Bahkan masih ada beberapa sekolah dalam merumuskan visi, misi dan tujuan sekolah yang tidak jelas, dan tidak sesuai dengan kondisi yang ada. Perumusan visi dan misi sekolah masih menjiplak dan tidak menggambarkan otonomi otonomi sekolah. ${ }^{8}$

Ungkapan ini membuktikan bahwa seorang pemimpin apapun wujudnya, dimanapun letaknya dan selalu mempunyai beban untuk mempertanggungjawabkan kepemimpinanya. Pemimpin seperti ini lebih banyak bekerja dibandingkan berbicara, lebih banyak memberikan contoh-contoh yang baik dalam kehidupanya dibandingkan berbicara tanpa bukti dan lebih banyak berorientasi pada bawahan dan kepentingan umum dibandingkan orientasi dan kepentingan sendiri.4 Pada dasarnya anggota organisasi memang butuh pemimpin yang dapat memberikan contoh. Hal ini memberikan stimulus kepada anggota organisasi serta menimbulkan respon untuk mengimpilikasikan tugas masingmasing anggota. Kepekaan anggota organisasi harus dibangun dengan perilaku nyata dari seorang figur pemimpin. Dengan hal ini, implikasi dari perilaku pemimpin menjadi bacaan wajib bagi seluruh anggota organisasi.

Sebuah lembaga tentunya memiliki tujuan yang ingin dicapai, dan tujuan tersebut akan dikembangkan dengan berbagai cara melalui kegiatan-kegiatan produktif sehingga apa yang diinginkan dapat tercapai. Peran kepala sekolah sebagai agen perubahan (agen of change) sangat penting dalam mencapai perubahan tersebut, maka dari itu diperlukan pemimpin yang benarbenar memikirkan suatu cara yang bagus dalam mengelola lembaga untuk mewujudkan visi misi atau tujuan yang telah dirumuskan. Dapat dilihat di MIN 1 Bantul, dimana kepala sekolah benar-benar memiliki keinginan untuk menjadikan madrasah sebagai unggulan dan terbaik dari sekolah-sekolah lain. Kemudian mampu bersaing dalam menghadapi perubahan zaman dan globalisasi. Hal ini terlihat dalam tuangan"visi dan misi sekolah ini,

\footnotetext{
${ }^{7}$ Wahyudi, Kepemimpinan Kepala Sekolah Dalam Organisas Pembelajar: Learning Organization, (Bandung: Alfabeta, 2009), hlm.8

${ }_{8}$ Irwana, Ade, Kepemimpinan Visioner Kepala Sekolah Dan Kinerja Guru Terhadap Efektifitas Sekolah Di Sekolah Dasar, Journal Administrasi Pendidikan, Vol. XXII, Oktober 2015, hlm. 104-119.
} 
yang kemudian dapat terealisasi dengan baik dan terus berkembang dari tahun ke tahun"berikutnya.

Berdasarkan latar belakang diatas, maka penulis merumuskan masalah penelitian tentang "Analisa kepemimpinan visioner dalam mewujudkan Visi Misi Sekolah di MIN 1 Bantul"? hasil dari paper ini diharapkan dapat memberikan informasi tentang pentingnya kepemimpinan visioner dalam mewujudkan visi misi Sekolah di MIN 1 Bantul.

\section{B. METODE PENELITIAN}

Pendekatan penelitian ini adalah kualitatif fenomenologis. Pendekatan ini dipilih secara kualitatif karena objek penelitian ini adalah perilaku atau aktivitas beberapa orang. Menurut Moleong penelitian kualitatif adalah penelitian yang bermaksud untuk memahami fenomena apa yang dialami oleh subjek peneliti. 9 Data dikumpulkan melalui wawancara dengan informan dan pengamatan langsung di lapangan, kemudian dianalisis secara induktif. Salah satu bentuk penelitian kualitatif yang memang dapat digunakan terutama untuk mengembangkan teoriteori yang diangkat dari beberapa latar belakang penelitian yang serupa, sehingga teori dapat dihasilkan yang dapat ditransfer ke situasi yang lebih luas dan lebih umum. Penggunaan pendekatan fenomenologis dalam penelitian ini dimaksudkan untuk dapat menggambarkan gejala atau fenomena yang terlihat dari objek penelitian.

\section{HASIL DAN PEMBAHASAN}

Kepemimpinan kepala

sekolah adalah konsep yang sangat dekat dengan keberhasilan dalam mencapai tujuan sekolah. Kepemimpinan memiliki berbagai macam variasi, kepemimpinan juga menentukan bagaimana perjalanan sekolah dalam mencapai tujuannya. Peran utama kepala sekolah adalah sebagai pemimpin pendidikan. Kepemimpinan pendidikan mengacu pada kualitas khusus yang harus dimiliki oleh setiap kepala sekolah untuk memikul tanggung jawabnya dalam mencapai tujuan yang diinginkan. Seorang kepala sekolah harus tahu persis apa yang ingin dicapai (visi) dan bagaimana cara mencapainya (misi). Seorang kepala sekolah yang visioner memahami betapa pentingnya mengundang semua pemangku kepentingan di sekolahnya untuk bersama-sama mencapai visi yang telah dirumuskan bersama. Namun harapan kepala sekolah yang memiliki semangat kepemimpinan visioner belum

${ }^{9}$ Moleong, L.J, Metodologi Penelitian Kualitatif, (Bandung: PT Remaja Rosdakarya, 2011), hlm.87. tentu mampu membawa lembaganya menjadi sekolah yang unggul di Indonesia.

Kepemimpinan visioner adalah kemampuan pemimpin dalam mencipta, merumuskan, mengkomunikasikan/mensosialisasikan/

mentransformasikan dan mengimplementasikan pemikiran-pemikiran ideal yang berasal dari dirinya atau sebagai hasil interaksi sosial diantara anggota organisasi dan stakeholders yangdiyakini sebagai cita-cita organisasi dimasa depan yang harus diraih ataudiwujudkan melalui komitmen semua personil. ${ }^{10}$ Pemimpin visoner merupakan pemimpin yang memiliki dan selalu berorientasi ke depan, apa yang ingin diwujudkan di masa depan dari realitas yang sedang dihadapi. Bagi pemimpin visioner, tatkala melihat batu misalnya. Di benaknya tergambar keinginan untuk membuat rumah yang besar dan megah. Pemimpin yang visioner itu penting dan menentukan hidup matinya organisasi. ${ }^{11}$

Kepemimpinan visioner menurut Ibnu Nasir dalam journal yang ditulis oleh susanti dan sumadi menjelaskan bahwa visioner adalah gaya kepemimpinan kepala sekolah untuk memajukan lembaga yang dipimpinnya yang memiliki visi dan misi yang jelas dalam organisasi, cerdas dalam mengamati suatu peristiwa di masa depan, memiliki visi dan misi yang jelas, seorang pemimpin yang cerdas dalam mengamati suatu peristiwa di masa depan, dapat membangkitkan semangat anggotanya, memotivasi dan membangun imajinasi mereka, membuat organisasi lebih hidup, melalui komitmen semua anggota organisasi, dan juga melalui proses sosialisasi, transformasi, implementasi ide-ide ideal oleh pimpinan organisasi, memberi makna dalam kerja dan upaya, arah, dan upaya yang dilakukan berdasarkan pada visi yang jelas menuju kepemimpinan visioner, kepala sekolah harus memiliki langkah-langkah seperti menciptakan visi dan misi, merumuskan visi dan misi, mengubah visi dan misi, implementasi visi dan misi. ${ }^{12}$

Rosmiati dan Kurniadi menjelaskan agar menjadi pemimpin yang visioner, maka seseorang harus: (a) Memahami Konsep Visi. Visi adalah idealisasi pemikiran tentang masadepan organisasi yang merupakan kekuatan kunci bagi perubahanorganisasi yang menciptakan budaya dan perilaku organisasi yang maju danantisipatif

${ }^{10}$ Muuhammad Fadhli, Kepemimpinan Kepala Sekolah Yang Efektif Dalam Menciptakan Sekolah Efektif, Journal Tarbiyah Vol.23, 1 Januari-Juni 2016

${ }^{11}$ Marno, Islam By Management and Leadership, (Jakarta: Lintas Pustaka, 2007), hlm.87

${ }^{12}$ Ninuk Endah Susanti dan Sumadi, Dedy Hermanto Karwan, The Principal Visionair Leadership of Islamic Integrated Elementary School Baitul Jannah Bandar Lampung, Journal of Education and Practice, Vol.10, 2019, hlm.49-55 
terhadap persaingan global sebagai tantangan zaman. "Visionary leadership" adalah visi kepemimpinan yang harus dimiliki berdasarkanrambu-rambu tersebut di atas untuk mewujudkan sekolah yang bermutu. (b) Memahami Karaktersitik dan Unsur Visi. Suatu visi memiliki karakteristiksebagai berikut: (1) memperjelas arah dan tujuan, mudah dimengerti dandiartikulasikan, (2) mencerminkan cita-cita yang tinggi dan menetapkanstandar of excellence, (3) menubuhkan inspirasi, semangat, kegairahan dankomitmen,(4) menciptakan makna bagi anggota organisasi, (5) merefleksikankeunikan atau keistimewaan organisasi, (6) menyiratkan nilai-nilai yangdijunjung tinggi oleh organisasi, (7) konstektual dalam arti memperhatikansecara seksama hubungan organisasi dengan lingkungan dan sejarahperkembangan organisasi yang bersangkutan. (c) Memahami Tujuan Visi. Visi yang baik memiliki tujuan utama yaitu: (1) memperjelas arah umum perubahan kebijakan organisasi, (2) memotivasikaryawan untuk bertindak dengan arah yang benar, (3) membantu prosesmengkoordinasi tindakan-tindakan tertentu dari orang yang berbeda-beda. ${ }^{13}$

Langkah-langkah dalam mewujudkan kepemimpinan yang visioner adalah menjadi salah satu instrumen yang harus ditempuh oleh kepala sekolah dalam mengembangkan dan memajukan lembaga sekolah yang sedang di kelola. Kepala sekolah MIN 1 bantul merupakan kepala sekolah yang memiliki langkah-langkah visioner dalam mewujudkan visi-misi sekolah MIN 1 Bantul.

1. Langkah-langkah Kepemimpinan Visioner di MIN 1 Bantul

a. Penciptaan Visi

Kemampuan kepemimpinan menurut Hidayah 14 adalah untuk menciptakan dan mengartikulasikan kenyataan, dapat dipercaya, dan menarik tentang masa depan organisasi atau inti dari organisasi yang terus tumbuh dan meningkat. Ini berarti bahwa sekolah harus futuristik dan tidak menjajakan sesuatu yang telah basi atau sesuatu yang tidak berguna untuk masa depan karena sudah usang. Tahapan penciptaan visi, menurut Ani Kalayjian, seorang visioner yang mampu menciptakan visi yang jelas dan terarah melalui beberapa tahapan, yang jelas dan terarah

\footnotetext{
${ }^{13}$ Rosmiati, T dan Kurniady, D. A., Kepemimpinan Pendidikan, (Bandung: Alfabeta, 2010), hlm. 143-144

${ }^{4}$ Hidayah, Nurul. Kepemimpinan Visioner Kepala Sekolah. Dalam Meningkatkan Mutu Pendidikan, (Yogyakarta: Ar-Ruzz Media, 2015), hlm. 50
}

melalui Trend Watching (prediksi) dan Envisioning (observasi). ${ }^{15}$

Berdasarkan hasil wawancara yang telah dilakukan, Ahmad Musyadad selaku kepala sekolah MIN 1 Bantul mengatakan bahwa beliau tidak mengubah sedikitpun visi maupun misi di sekolah ini, beliau mengatakan visi dan misi sekarang ini sudah sangat bagus, hanya saja hal yang perlu dilakukan adalah bagaimana beliau sebagai pemimpin atau kepala sekolah mampu mengembangkan tuangan-tuangan disetiap visi sehingga apa yang menjadi tujuan tersebut dapat tercapai sesuai dengan apa yang diinginkan. Kemudian mampu menjaga elektabilitas madrasah agar tidak menurun.

Kepala sekolah dan seluruh jajaran staf dan guru juga melakukan pembenahan setiap tahun untuk melihat bagaimana keberhasilannya dalam menerapkan visi misi madrasah, jika masih ada kekurangan maka kepala sekolah dan seluruh tenaga pendidik akan melakukan evaluasi dan melakukan rapat untuk membenahi kekurangankekurangan yang belum terealisasikan pada tahun sebelumnya untuk memperbaiki kekurangan untuk proses mendatang.

Untuk mengimplementasikan kepemimpinan yang visioner beliau berpegang teguh pada prinsip-prinsip kepemimpinan yang baik untuk dapat menstabilkan visi yang telah terancang dengan berbagai tindakan, seperti mengarahkan guru untuk mengupgrade sistem pembelajaran yang diterapkan, mengkomunikasikan programprogam sekolah kepada seluruh stakeholder secara efektif, serta memikirkan dan mempertimbangkan berbagai kemungkinan di masa yang akan datang dengan berbagai rencana berdasarkan kebutuhan masyarakat.

b. Merumuskan Misi

Kepemimpinan visioner dalam tugas perumus visi adalah kesadaran akan pentingnya visi dirumuskan dalam statement yang jelas agar menjadi komitmen semua personil dalam mewujudkannya sehingga pemimpin berupaya mengelaborasi informsi, cita-cita, keinginan pribadi dipadukan dengan cita-cita/gagasan personil lain dalam forum komunikasi yang intensif sehingga menghasilkan kristalisasi visi organisasi.

Visi perlu dirancang dalam pernyataan yang jelas dan tegas dan perumusannya harus melibatkan stakeholders dengan fase kegiatan sebagai beirkut: (1), Pembentukan dan perumusan visi oleh anggota tim kepemimpinan, (2), Merumuskan strategi secara consensus, (3),

15 Ani Kalayjian, DR. 12 Secrets of Visionary Leaders Meaningfulworlds.com- https://goo.gl/mfa4mA 
membulatkan sikap dan tekad sebagai total commitment untuk mewujudkan visi ini menjadi suatu kenyataan.

Teori diatas sejalan dengan penelitian yang telah dilakukan dimana Ahmad Musyadad selaku kepala sekolah menerangkan bahwa dalam sebuah lembaga visi dan misi merupakan suatu hal yang sangat penting karna tujuan akhirnya adalah mencapai visi misi itu. Di MIN 1 Bantul visi misi dirancang secara bersama oleh seluruh warga madrasah yang akan menghadirkan pakar ahli, dan juga pengurus UPT, paguyuban anak murid, dan Masyarakat dan kemudian bersama-sama menjabarkan sebuah visi dan misi yang akan dijadikan acuan dalam mewujudkan kemajuan madrasah. Visi dan misi yang telah disusun kemudian disepakati bersama dan akan di tuangkan dalam surat keputusan (SK) visi misi. Visi dan misi direview setiap tahun dengan tujuan apakah ketercapaian visi misi sesuai dengan harapan yang diinginkan oleh pengelola madrasah yakni kepala sekolah, guru dan masyarakat di lingkungan sekitar madrasah. ${ }^{16}$ Setelah visi misi tersusun barulah semua yang terkait dalam lingkungan sekolah ikut membantu dan merealisasikan apa saja yang telah disepakati, jarang ada kendala yang menghalangi kegiatan ataupun rencana dalam penerapan visi dan misi ini hanya saja sering terjadi keterlambatan dan ketidakmampuan siswa dalam mewujudkan visi dan misi yang telah disepakati. Walaupun begitu tak menjadi halangan untuk tetap mewujudkannya. Perlu adanya kesabaran, ketekunan serta perbaikan-perbaikan dalam menerapkannya.

c. Transformasi Visi

Nenus berpendapat bahwa transformasi Visi harus dapat membangun kepercayaan di lingkungan sekolah, kemampuan menjelaskan, mengutarakan visi dan misi, menyampaikan visi dan misi sekolah, mengembangkan gambar, tepat sesuai dengan tujuan sekolah sambil berkolaborasi. ${ }^{17}$ Mengubah visi dan misi sekolah adalah hal yang harus di lakukan sehingga para pemimpin visioner harus dapat berkomunikasi, bersosialisasi, serta berkolaborasi dengan orangorang untuk membangun, memelihara, dan mengembangkan visi mereka. ${ }^{18}$

Pertahankan, dan kembangkan visi yang mereka anut. Adapun kegiatan yang dilakukan

${ }^{16}$ Wawancara Dengan Kepala Sekolah, dilakukan Pada Tanggal 05 November 2019. Pukul 08:15.

${ }^{17}$ Nanus, Burt, Kepemimpinan Visioner, (Jakarta: Prenhalindo, 2001), hlm.55

18 Ninuk Endah Susanti dan Sumadi, Dedy Hermanto Karwan, The Principal Visionair Leadership of Islamic Integrated Elementary School Baitul Jannah Bandar Lampung, Journal of Education and Practice, Vol.10, 2019, hlm.49-55 kepala sekolah dalam mewujudkan visi misi ialah membentuk kegiatan-kegiatan ekstrakulikuler guna mengembangkan segala kreatifitas dan minat siswa. Didalam penyajian konsep kurikulum MIN 1 Bantul selalu pelajaran dengan tujuan visi misi, dimana isi visi misi selalu dimasukkan dalam setiap proses belajar. Selain itu dalam kurikulum MIN 1 Bantul dituangkan pendidikan lingkungan hidup yang bertujuan untuk mengenalkan apa saja yang ada disekitar lingkungan mereka dan juga membiasakan siswa bertanggung jawab terhadap apa yang ada dilingkungan sekitar mereka.

Adapaun tujuan dari review visi misi adalah untuk mewujudkan tercapainya tujuan visi misi yang telah disepakati bersama dan telah dituangkan dalam kurikulum. Peran kepala sekolah adalah mengingatkan kembali kepada guru dengan harapan semua kegiatan yang belum terealisasi untuk segera di realisasikan.

d. Implementasi Visi

Implementasi visi merupakan Kemampuan pemimpin dalam menjabarkan dan menterjemahkan visi ke dalam tindakan. Visi merupakan peluru bagi kepemimpinan visioner. Visi berperan dalam menentukan masa depan organisasi apabila dimplementasikan secara komprehensif. Kepemimpinan yang bervisi bekerja dalam empat pilar yaitu: (1) Penentu Arah, (2) Agen Perubahan, (3) Juru Bicara, (4) Pelatih dan komunikator. ${ }^{19}$

Lembaga pendidikan harus mempunyai Visi dan Misi sebagai dasar dan tujuan. Dengan dasar dan tujuan tersebut, suatu lembaga akan bisa menentukan pilihan langkah menuju terwujudnya dasar dan tercapainya tujuan suatu lembaga tersebut. Demikian juga dengan MIN Jejeran Wonokromo Bantul atau sekarang dikenal dengan MIN 1 Bantul adalah salah satu lembaga pendidikan formal yang mempunyai dasar dan tujuan. Maka MIN 1 Bantul mempunyai Visi dan Misi dan tujuan, yaitu:

1) Visi Misi MIN 1 Bantul

Visi atau wawasan adalah suatu pandangan yang merupakan kristalisasi dan intisari dari suatu kompetensi (competence), kemampuan (ability), dan kebiasaan (self efficacy), dalam melihat, menganalisis, dan menafsirkan. Penetapan Visi ini berpijak pada peningkatan kualitas di masa depan.

Seiring perkembangan zaman, MIN 1 Bantul mengalami beberapa kali revisi visi dan misi. Berikut ini visi MIN 1 Bantul yang terbaru yaitu "Terwujudnya Warga Madrasah Religius, Berprestasi, Cerdas, sebagai Penyelamat

${ }^{19}$ Nanus, Burt, Kepemimpinan Visioner, (Jakarta: Prenhalindo, 2001), hlm.95 
Lingkungan Hidup, Modern, Sehat, Ramah anak, dan Siaga Bencana".

Misi MIN 1 Bantul Misi merupakan jabaran dari visi. Adapun misi dari MIN 1 Bantul adalah:

a) Mewujudkan warga Madrasah sebagai generasi yang santun, taat beribadah serta terampil dalam pengamalan.

b) Menguatkan pendidikan agama di Madrasah.

c) Meningkatkan kualitas pendidik dan tenaga kependidikan.

d) Mengembangkan kurikulum yang adaptif.

e) Mengupayakan ketersediaan sarana dan prasarana pendidikan yang refresentif.

f) Menerapkan evalusi pembelajaran sebagai basis peningkatan mutu pendidikan.

g) Mengoptimalkan pembelajaran berbasis teknologi informasi dan PAKEM.

h) Meningkatkan kesiapsiagaan warga Madrasah menghadapi bencana.

i) Menerapkan manajemen berbasis madrasah dan mengoptimalkan peran serta masyarakat.

j) Membudayakan perilaku hidup bersih, sehat dan cinta lingkungan hidup dan melestarikannya.

k) Mengupayakan iklim yang kondusif bagi tumbuh kembang anak sehingga peka terhadap lingkungan.

l) Mengembangkan program dan kegiatan untuk mengoptimalkan bakat dan minat siswa.

2. Langkah-Langkah Dalam Pencapaian Kepemimpinan Visioner di MIN 1 Bantul

Adapun langkah-langkah dalam pencapaian kepemimpinan visioner MIN 1 Bantul adalah melakukan review visi misi dalam satu kali setahun yang berisikan evaluasi pencapaian yang telah dilakukan dan yang belum di lakukan. Adapaun kegiatan yang belum terlaksanakan akan diteruskan dan dilaksanakan pada tahun selanjutnya. Hal yang dievaluasi adalah:

a. Kegiatan religius;

Religius adalah sikap yang patuh dalam melaksanakan ajaran agama yang dianutnya, toleran terhadap pelaksanaan ibadah agama lain, dan hidup rukun dengan pemeluk agama lain.

Dalam kegiatan ini para siswa belajar tentang tata cara sholat dan belajar mengaji. Guru juga melakukan evaluasi terkait dengan siswa yang belum bias menerapkan sholat duha secara rutin. Selain itu guru mengajarkan siswa yang belum bisa mengaji sampai mereka benar-benar bisa membaca alquran.

b. Program mencerdaskan madrasah seperti:

1) Peningkatan Akademik.

Kegiatan belajar mengajar tidak selalu mulus dan sesuai dengan apa yang diinginkan, selalu ada hambatan serta masalah yang akan dihadapi baik itu oleh gur maupun siswa. Melalui proses belajar mengajar pendidik akan mengetahui sejauh mana pemahaman siswa, ketika akhir pembelajaran akan terlihat hasil dari kegatan belajar tersebut, jika hasil belajar masih kurang dan tidak sesuai dengan apa yang diinginkan maka guru harus melakukan evalusi dala kegiatan belajar.

Hal yang dievaluasi adalah bagaimana ketercapaian siswa dalam kegiatan pembelajaran terutama apa saja kendala yang dihadapi siswa ketika peroses pembelajaran. Setelah mengetahui kendala yang dialami siswa maka guru melakukan pembenahan dan merancang metode serta tekhnik yang akan digunakan agar proses kegiatan dapat sesuai dengan apa yang diinginkan.

2) Terdapat banyak program-program kegiatan yang telah disusun atau dirancang dalam proses belajar siswa serta target yang harus dicapai. Target tersebut sudah tertuang dalam kurikulum dan akan menjadi acuan dalam menilai proses belajar siswa. Contohnya seperti KKM. Setiap sekolah memiliki KKM yang sama maka dari itu kita sebagai tenaga pendidik harus memiliki kemampuan yang propfesional guna mencapai tujuan yang diinginkan.

c. Program sehat

Dalam kegiatan program sehat sekolah melakukan kegiatan rutin setiap hari seperti menyapu halaman, menyiram halaman, menanam bunga, merawat pohon pohon yang ada disekitar sekolah, mencuci tangan, menggosok gigi, membersikan sisa makanan dan kemudian membuang sampah di tempat yang telah disediakan.

Sekolah juga memiliki ruang kesehatan khusus untuk anak-anak belajar tentang bagaimana cara hidup sehat dan bagaimana cara mere mereka menangani ketika dia sakit.

Semua itu dilakukan dan difasilitasi oleh sekolah agar siswa disekolah dapat belajar dengan nyaman serta lingkungan tempat belajar siswa bersih dan sehat.

Pengimplementasian Visi Misi di MIN 1 Bantul terlaksana dengan baik, dapat dilihat ketika memasuki gerbang sekolah ini, disebelah sekolah tersebut ada taman yang berisi tanaman, pepohonan, bunga dan masih banyak lagi. Dimana fasilitas tersebut dijadikan sebagai tempat siswa melakukan pembiasaan tentang bagaimana cara menjaga lingkungan hidup disekitar mereka. 
Ketika memasuki halaman sekolah, terlihat banyak sekali piala-piala berjejeran rapi didalam lemari dan terpampang disetiap tembok sekolah segala prestasi-prestasi yang pernah diraih oleh lembaga, guru dan peserta didik sekolah ini. Dalam mengembangankan visi dan misi madrasah membiasakan peserta didik untuk tetap melakukan sholat duha setiap hari, kemudian mengucapkan salam ketika bertemu orang lain dan madrasah ini selalu mengadakan kegiatan-kegiatan keislaman yang dimana kegiatan tersebut dilakukan dengan mengikutsertakan warga masyarakat sekitar guna untuk mempererat tali silaturrahmi antara lembaga dengan masyarakat sekitar madrasah. ${ }^{20}$

Uraian diatas diperkuat dengan pernyataan dari guru dan siswa disekolah tersebut dimana guru-guru mengatakan bahwa mereka nyaman dan sangat menyukai cara kerja dan cara kepemimpinan kepala sekolah yang memandang arah kedepan dengan orientasi pada proses pemberian pendidikan yang tepat untuk mengarahkan peserta didik dalam menghadapi era globalisasi. Hal ini ditunjukan oleh kepala sekolah dalam kemampuan merencanakan, komunikasi, pengelolaan, dan pengambilan keputusan dengan berpandangan kedepan.

Kepala sekolah juga perlu mengantisipasi kelemahan yang akan dihadapi ketika ingin menjadi pemimpin visioner, agar tidak terjadi kegagalan dalam memimpin. Adapun kelemahankelemahan tersebut meliputi: ${ }^{21}$

1) Tipe kepemimpinan visioner yang lebih berfokus pada arah organisasi masa depan akan lebih tersita oleh eksplorasi masa depan. Fokus semacam ini sangat berisiko, karena kurangnya disiplin dan kepatuhan dalam melakukan pengendalian keuangan dan penguatan struktur, sehingga kemungkinan kegagalan cukup tinggi.

2) Pemimpin kurang memiliki pengetahuan tentang fungsi-fungsi organisasional keseharian dan cendrung mengabaikan stabilitas jangka pendek karena lebih mengutamakan bagaimana menentukan strategi-strategi jangka panjang agar tercapainya visi organisasi.

3) Pemimpin visioner cendrung membuat keputusan berdasarkan nilai-nilai yang diyakini dan independen.

\footnotetext{
${ }^{20}$ Observasi di MIN 1 Bantul, Senin 28 Oktober 2019.

${ }^{21}$ Cindy Satrio, dkk, Tugas Kepemimpinan Strategik Gaya Kepemimpinan Transdevis, https://www.academia.edu, diakses Pada Tanggal 28 Oktober 2019, jam: 21:25.
}

\section{SIMPULAN DAN SARAN}

Pemimpin visoner merupakan pemimpin yang memiliki dan selalu berorientasi ke depan, apa yang ingin diwujudkan di masa depan dari realitas yang sedang dihadapi. Langkah-langkah dalam mewujudkan kepemimpinan yang visioner adalah menjadi Salah satu instrumen yang harus ditempuh oleh kepala sekolah dalam mengembangkan dan memajukan lembaga sekolah yang sedang di kelola. Kepala sekolah MIN 1 bantul merupakan kepala sekolah yang memiliki langkahlangkah visioner dalam mewujudkan visi-misi sekolah MIN 1 Bantul. Adapun langkah-langkah kepemimpinan visionir yang dilakukan oleh kepala sekolah MIN 1 Bantul tercermin dalam 4 hal yaitu (1) Penciptaan Misi, (2) Merumuskan Misi, (3) Transformasi Visi, dan (4) Implementasi Visi.

Saran dalam penelitian ini bahwa kepemimpinan visioner dalam sebuah lembaga pendidikan sangat penting. Berdasarkan fakta dilapangan bahwa kepemimpinan visioner sekolah MIN 1 Bantul masih kurang efektif maka saran penelitian ini adalah seabagai berikut:

1. Kepala sekolah Perlu meningkatkan kembali kinerja para guru demi mewujudkan visioner kepala sekolah.

2. Kepala sekolah perlu meninjau kembali tekait dengan hambatan atau permasalahan dalam mewujudkan visi dan misis sekolah.

3. Kepala sekolah diharapkan terus melakukan peningkatkan solidaritas antara tenaga pendidik (guru), siswa dan lingkungan masyarakat sekitar.

\section{DAFTAR RUJUKAN}

Irwana, Ade, Kepemimpinan Visioner Kepala Sekolah Dan Kinerja Guru Terhadap Efektifitas Sekolah Di Sekolah Dasar, Journal Administrasi Pendidikan, Vol. XXII, Oktober 2015, hlm. 104-119.

Moleong, L.J, Metodologi Penelitian Kualitatif, Bandung: PT Remaja Rosdakarya, 2011.

Ninuk Endah Susanti dan Sumadi, Dedy Hermanto Karwan, The Principal Visionair Leadership of Islamic Integrated Elementary School Baitul Jannah Bandar Lampung, Journal of Education and Practice, Vol.10, 2019.

Observasi di MIN 1 Bantul, Senin 28 Oktober 2019.

Rohmat, Kepemimpinan Pendidikan, Purwokerto: STAIN Press, 2010.

Tim Dosen Administrasi Pendidikan Universitas Pendidikan Indonesia, Manajemen Pendidikan Bandung: Alfabeta, 2011. 
Wawancara Dengan Kepala Sekolah, dilakukan Pada Tanggal 05 November 2019. Pukul 08:15.

Muuhammad Fadhli, Kepemimpinan Kepala Sekolah Yang Efektif Dalam Menciptakan Sekolah Efektif, Journal Tarbiyah Vol.23, 1 Januari-Juni 2016

Marno, Islam By Management and Leadership, Jakarta: Lintas Pustaka, 2007,

Rosmiati, T dan Kurniady, D. A., Kepemimpinan Pendidikan, Bandung: Alfabeta, 2010.

Huda, Muhammad Nailul, Marhadi, Hendri, \& Noviana, Eddy. (2018). Kompetensi Pedagogik Mahasiswa Program Studi Pendidikan Guru Sekolah Dasar. Jurnal Online Mahasiswa (JOM) Bidang Keguruan dan Ilmu Pendidikan, 5(1), 1-13.

James, William. The principles of psychology: Read Books Ltd. 2013.

Hidayah, Nurul. Kepemimpinan Visioner Kepala Sekolah. Dalam Meningkatkan Mutu Pendidikan, Yogyakarta: Ar-Ruzz Media, 2015.

Tim Dosen Administrasi Pendidikan Universitas Pendidikan Indonesia, Manajemen Pendidikan (Bandung: Alfabeta,2011), hlm.143

Cindy Satrio, dkk, Tugas Kepemimpinan Strategik Gaya Kepemimpinan Transdevis, https://www.academia.edu, diakses Pada Tanggal 28 Oktober 2019, jam: 21:25. 